\title{
Effect of Lime andTannin Dosage Against Productivity ofSapofNatural and Planted Nypa Palm
}

\author{
Setia Budi ${ }^{1}$, Arief RM Akbar ${ }^{2}$, Joko Purnomo ${ }^{3}$, Susi $^{4}$, \\ Hisyam Musthafa Al Hakim ${ }^{5}$ \\ ${ }^{I}$ Faculty of Forestry, Lambung Mangkurat University \\ ${ }^{2,3,4,5}$ Faculty of Agriculture, Lambung Mangkurat UniversityBanjarbaru City, South Kalimantan
}

\begin{abstract}
Research conducted by Akbar et all., (2015) showed that in general the Nypa Palmsap productivity remains low, whereas the required amount of sap relatively enough to produce the amount of brown sugar made many of them to be economical, there is no research about this, so research on productivity was needed. The research object is the population of Nypa Palm trees planted $\left(J_{I}\right)$ and a population of Nypa Palm trees that grow naturally $\left(J_{2}\right)$. In both populations tree fruit bunches is done wobble technique for tapping sap. The sap generated from both the tree population accommodated in containers that have been given treatment in the form of a mixture of lime and tannin (from jackfruit terrace), which is then measured to determine the sap productivity.The results showed that the average number of Nypa Palm sap obtained from measurements of the second week until the eighth week of each is 5,663 ml, 4,730 ml, 5,063 ml, 4,473 ml, 4,937 ml, 4,960 ml and 4,717 ml per stem per day. Dosage of a mixture of lime and tannin did not significantly affect the productivity of sap, but the type of Nypa Palm (naturalNypa Palm and plantedNypa Palm) has significant effect in which productivity of sap ofnatural Nypa Palm higher than the Nypa Palmsap of planted Nypa Palm with each value was $1,192.8 \mathrm{ml}$ and $618.95 \mathrm{ml}$ per stem per day.
\end{abstract}

\section{Introduction}

Indonesia as a developing country with a population of relatively high face two main issues of concern, namely the provision of food and feed on the one hand and on the other hand energy. The energy crisis at the end of 2005 which caused the price of oil reached the tallest in the history (of close to 150 US dollars per barrel), gives a clear picture of the inter-relationship between the two issues. When the price of oil increases, the price of some food commodities go up because they are caused by rising production costs and transportation as well as a declining supply of certain foodstuffs such as corn and sugar as a result partly diverted to energy production in major producing countries. Although food is renewable, but its production is limited by the capacity of natural resources such as soil and climate, while the main conventional energy such as oil and coal reserves are limited and can not be renewed. It has alerted all parties to find and develop alternative energy beyond fossil fuels.

The narrowing productive agricultural land on the island of Java due to the expansion of industrial and residential development at this time, forcing the government to seek the location of new land in the development of agricultural development.is an option that allows the development potential of land outside Java, especially on the island of Borneo which is generally dominated by marginal land. Productive land in Kalimantan, especially in South Kalimantan is dominated by dry land that is currently allocated for oil palm plantations owned by the government, private and cooperative. The majority of marginal land is wetlands also begun to be exploited by mustard oil plantations with land use change to suit the characteristics of the oil palm plantations.

The development of plant-based energy as an alternative energy must meet two basic requirements, ie the smallest chance ofraw materials used as food and the most minimal competition in terms of land use.In connection with this, the commodity most rational for biodiesel production is jarak pagar, kemiri sunan, and nyamplung because instead of food commodities, while the raw material for bio-ethanol is the most likely to use commodity aren and sago for three commodities is most small rivalry with food commodities and other commodity interests. Sugars that can be produced from aren, Nypa Palm and sago flour is the only food and alternative energy sources. Seeing these conditions, one of the potential wetlands that has not been touched are cropping Nypa Palm.With an average population stretches along the coastline, if they can be optimally utilized it will be able to provide value added economy is very significant for the life of coastal communities, during which only rely on marine catches.

Another advantage of the Nypa Palm plants are very suitable for the conservation of the environment, because this plant only once planted, and no replanting or rejuvenation, so once planted the land will be green forever.Nypa Palm utilization for the production of bio-ethanol is not a way to cut them down, but by tapping sap from any fruit bunches produced. Nypa Palm can grow from wetlands, brackish, and is periodically inundated land which at this location is not a lot of other commodities can be operated economically. The 
problem that is a challenge for commodities Nypa Palm is still limited cultivation of scientific and technological information provided, as long as these commodities in Indonesia is not yet commercially so untouched by the various research activities.Based on the descriptions above, the Nypa Palm is a crop that has advantages and promising prospects to be developed as an alternative energy source in the future as well as a source of new economy of coastal communities, especially in the area of South Kalimantan. Nypa Palm plants still commonly found in coastal areas of South Kalimantan, especially in the regency of Kotabaru, Tanah Bumbu, Tanah Laut, and Barito Kuala. Lodging in the first regency, a few years ago this Nypa Palm palm forest area has been opened (transformed to enable) for farming and making paddy fields, but over time it turns out farms and paddy field development plan is not running or do not achieve the desired result economically, so that there are currently vacant wetlands or open ponds and former former rice fields before making is indeed a Nypa Palm palm forest stands in the regency (Purnomo, et all, 2014).

\section{The specific objective}

The specific objective of this study was to determine the best Nypa Palm tapping techniques for optimization of yield sap from natural Nypa Palm and plantedNypa Palm as well as optimization of tapping the sap with some combination of preservatives (lime and tannins from jackfruit terrace).

\section{The importance of this research}

The utilization of marginal land, especially in wetlands today is very important because the expansion of non-agricultural economic activities in the productive land is almost inevitable.Nypa Palm natural been overlooked and only used by rural communities as a roofing material from palm leaves turned out to save a huge potential as food and renewable energy. To obtain a high economic value of the use of natural Nypa Palmor plantedNypa Palm necessary to find the way to the wiretapping technology and process technology into food and renewable energy that can be applied at the level of rural farming communities.

Tapping the appropriate technology needs to be done in order to obtain optimum results Nypa Palm sap in quantity. Without proper pretreatment before tapping it will not produce sap as expected. This constraint should look for a solution in the field, given the coastal communities where there Nypa Palm plants they are very minimal knowledge about cultivation and post-harvest handling of the Nypa Palm.

\section{A. Location of The Research}

\section{Research Method}

The research was conducted in the village of Swarangan and Pantai Harapan, Tanah Laut Regency, South Kalimantan Province. The location chosen was Nypa Palmplantation (planted Nypa Palm) in the Pantai Harapan village and naturalNypa Palm population in the Swarangan village.

\section{B. Materials and equipment}

The main materials used are the population of natural Nypa Palmand Nypa Palm were planted. The chemicals used are lime $(\mathrm{CaO})$ and a tannin solution of jackfruit wooden porch.

The tools used are the thermometer, hygrometer, refraktrometer, measuring cups, plastic bottles, plastic molding.

\section{Research Procedure}

To answer the purpose of optimization of productivity Nypa Palm sap in natural and cultivated as well as finding the best combination of natural ingredients preservative mixture of sap before cooking at room temperature conditions using a solution of lime $(\mathrm{CaO})$ and powder jackfruit wooden porch (tannin content), experimental design used a nested hierarchy where a combination of a mixture of lime solution and tannins powder of jackfruit wooden terrace $(\mathrm{C})$ is nested on the type of environment growing of Nypa Palm population (J) with a combination of the following composition:

a. Nypa Palm sap productivity in the two conditions (J):

$\mathbf{J}_{1}=$ natural Nypa Palm

$\mathrm{J}_{2}=$ planted Nypa Palm

Nypa Palm sap productivity studies on two conditions $(\mathrm{J})$ being treated equally in the form of a shake left and right as well as up and down each five times every morning and evening for two weeks.

b. combination of a mixture of lime and tannins of jackfruit wooden terrace as preservatives of sap $(C)$ :

$\mathrm{C}_{1}=3$ liters of water +100 gram of $\mathrm{CaO}+150$ gram of jackfruit wooden terrace

$\mathrm{C}_{2}=3$ liters of water +125 gram of $\mathrm{CaO}+125$ gram of jackfruit wooden terrace

$\mathrm{C}_{3}=3$ liters of water +150 gram of $\mathrm{CaO}+100$ gram of jackfruit wooden terrace 
Effect of Lime and TanninDosage Against Productivity of Sap of Natural and Planted Nypa Palm...

So there are 6 combinations treatment was repeated three times, so there are 18 experimental unit. The parameters observed and measured include Nypa Palm sap productivity per day per stalk.

\section{Data Analysis}

Data obtained from observations tabulated and analyzed by analysis of variance (ANOVA). If the result of analysis of variance showed the real effect, the testing continued with test means using BNT (Honestly Significant Difference) $5 \%$ significance level.

\section{A. Generally Description of The Study site}

\section{Result And Discussion}

Natural Nypa Palm population object being studied is located in the village of Swarangan, one of the villages which includes the Jorong District, whereas planted Nypa Palm population located in the village of Pantai Harapan which includes the Bumi Makmur District. Both districts are located in the Tanah Laut Regency, South Kalimantan Province.

The natural Nypa Palm population grew and developed predominantly along the river in the Swarangan village.From observations and information local people, this only leaves the use of plants to be used as roofing for housing in rural areas, and sticks from the leaves. Based on this, there is a description of many benefits that can be gave by Nypa Palm plants to the local people in particular, only a few have been exploited by the local people.

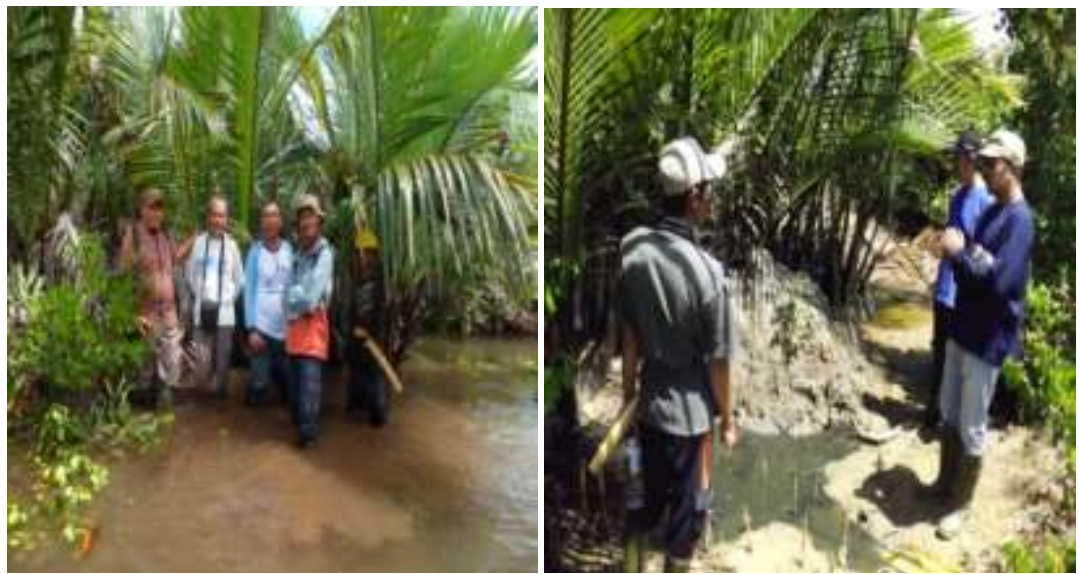

Pigure 1. Natural Nypa Palm Site

PlantedNypa Palm, as the result of the experiment conducted since 2011 by local people in collaboration with researchers from the University of Lambung Mangkurat, South Kalimantan, Indonesia is an information about the failure by these plants to be cultivated, because during this time, especially in Indonesia there is no Nypa Palm plants were cultivated. Thus, this fact gives hope that planted Nypa Palm that normally grow naturally can be cultivated into a garden, both small scale carried out by local people and large scale carried out by a small or large company for business purpose.

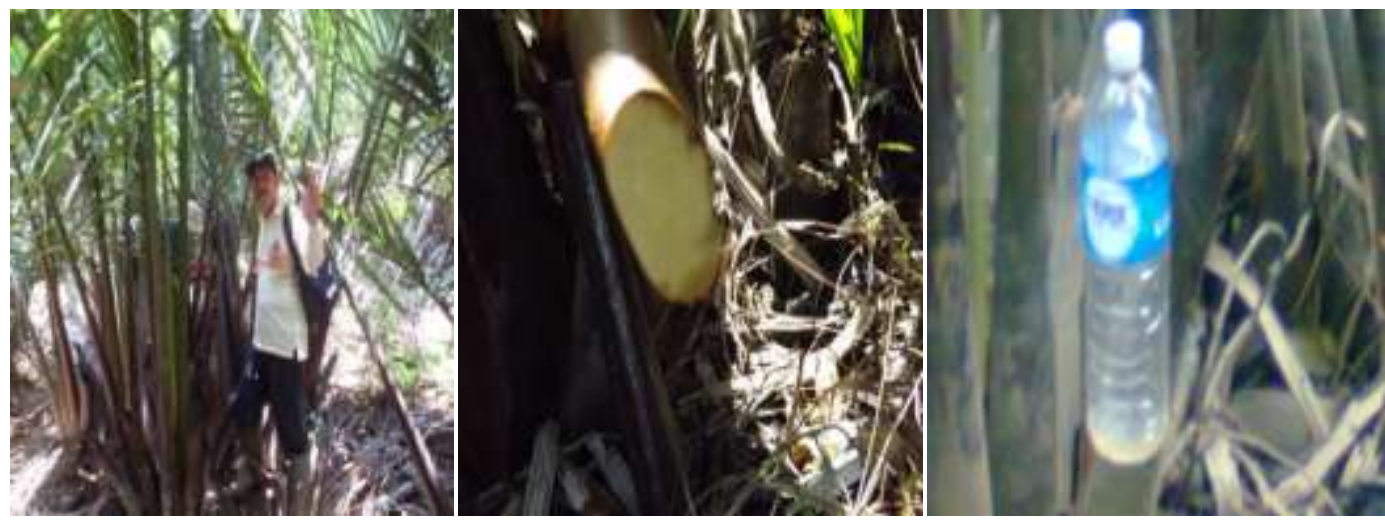

Pigure 2. Planted Nypa Palm Site and The Sap Tapping 


\section{B. Sap Productivity}

From the analysis of variance is known that the treatment on type of Nypa Palm plants (both natural and plantation) in second week is not significant, but in the third week and the next significant, whereas a dose of jackfruit terrace and lime mixture in this type of Nypa Palm real effect on tapping second week and third week, but in the next week no real effect.

Influential dose comparison terrace jackfruit and lime in this type of Nypa Palm plants on tapping second week and all three allegedly as a result of a mix between the core jackfruit and lime initially produce gas as well as an increase in temperature that cause blockage of the pores on the surface of tapping on the end of the stem (bunches) Nypa Palm fruit. This is consistent with the release mechanism in the field of tapping the sap is affected by temperature and humidity.In tapping next week dose comparison terrace jackfruit and lime do not significantly affect the sap productivity. This is presumably because mixing terrace jackfruit and lime did not produce more gas, and the temperature becomes normal.Effect of Nypa Palm type on productivity in fact kind of sap produced, which average productivity at planted Nypa Palm amounted to $618.95 \mathrm{ml} / \mathrm{stalk} /$ day, and the average productivity of the natural Nypa Palm sap of 1,192.8 $\mathrm{ml} /$ stalk / day, because there differences in the characteristics of the type of Nypa Palm that grow naturally (type 2), and the type of plantedNypa Palm (type 1).Nypa Palm that grow naturally look bigger, longer leaves and the fruit stalk is longer and larger.Besides, Nypa Palm that grow naturally in terms of older age, and grow stronger.

\section{A. Conclusion}

\section{Conclusion And Recommendation}

1. The average number of Nypa Palm sap produced from measurements thesecond week until the eighth week of each is $5,663 \mathrm{ml}, 4,730 \mathrm{ml}, 5,063 \mathrm{ml}, 4,473 \mathrm{ml}, 4,937 \mathrm{ml}, 4,960 \mathrm{ml}$, and 4,717ml per stem per day.

2. Treatment of dose tannins from jackfruit terrace and limestone can be said not significantly affect the productivity of Nypa Palm sap, but the type of Nypa Palm plants (natural Nypa Palm and planted Nypa Palm) significantly affected the productivity of Nypa Palm sap, which natural Nypa Palm sap productivity is higher than the productivity of planted Nypa Palm sap, each of 1,19.8ml / stalk / day and 6,18.95 $\mathrm{ml} /$ stalk / day.

\section{B. Recommendation}

1. From the results of the research shows that the sap obtained from the bunch (stem) fruit of Nypa Palm plants can be used as raw materials to produce brown sugar with a particular treatment. The discovery could be very valuable to be delivered and applied to the rural people who happen to live around the forest Nypa Palmarea, either naturally grown or planted in an effort to provide additional revenue for the communities concerned. In an effort to realize this, it is suggested to local authorities at the location of this research specifically or other areas that are interested can adopt the results of this study,

2. Further research is needed on the development of bio reactor design for processing into bio-ethanol of Nypa Palm sap in rural scale, so that the potential economic of Nypa Palm plants can be more widely known.

\section{References}

[1]. Anonymous, 2008. Nypa Palm Palm (Nypa fruticans). Mangrove Palm. http: //www.palm-Nypa Palm.htm. Date modified: 05/17/2008

[2]. Akbar, ARM. Purnomo, J ,. Roles, S.B and Susanto, O., 2015. Brown Sugar Processing Technology of Nypa Palm Plants. www.Nypa Palmcenterindonesia. (Accessed January 2, 2015)

[3]. Alrasyid, H. 1995. Biology Environment of Nypa PalmStands in Sungai Durian Forest. West Kalimantan. Research Bulletin and Forestry Development. Jakarta

[4]. Bandini, Y. 1986. The Nypa Palm New Natural Sweetener. PT. Penebar Swadaya. Jakarta.

[5]. Davis, TA 1986. Nypa Palm Palm in Indonesia. A source of Unlimited Food and Energy. Iard Journal 8 (2): $34-38$

[6]. Fadillah, H. 2014. Effect of Temperature and Pyrolysis Time Against Rendement and Quality of Liquid Smoke of shells of Rubber Fruit (Hevea brasiliensis). Thesis Faculty of Agriculture, University of Mangkurat. Banjarbaru (Unpublished)

[7]. Heyne, K. 1987. I. Indonesian Useful Plants Forestry Research and Development Agency. Department of Forestry. Jakarta: 487-490

[8]. Hanafiah, K.A. 1997. Design of Experiments. Theory and Applications. PT. Raja Grafindo Persada. Jakarta

[9]. Lembaga Biologi Nasional, 1987. Palm Indonesia. Lembaga Ilmu Pengetahuan Indoesia (LIPI). Bogor

[10]. Prihandana, R and Handoko, R. 2007. Green Energy. Towards Wise selection of Independently Stateof energy. Penebar Swadaya. Bogor

[11]. Purnomo, J., Akbar ARM., Roles, S.B and Susanto, O. 2015. The pattern of propagation of Nypa Palm clumps. www.Nypa Palmcenterindonesia. (Accessed January 2, 2015)

[12]. Wilkipedia, 2008. Nypa Palm. http ://id. Wilkipedia.Org/wiki/Nypa Palm. Date modified : 5/17/2008 
Effect of Lime and TanninDosage Against Productivity of Sap of Natural and Planted Nypa Palm...

Appendix 1. Data of produced sap amount (ml) of various treatments obtained in the second weekandAnalysis of Variance

\begin{tabular}{|c|c|c|c|c|c|}
\hline \multirow{2}{*}{ Treatments } & \multicolumn{3}{|c|}{ Block } & \multirow{2}{*}{ Total } & \multirow{2}{*}{ Mean } \\
\hline & 1 & 2 & 3 & & \\
\hline $\mathrm{d}_{1} / \mathrm{j}_{1}$ & 340 & 400 & 430 & 1,170 & 390 \\
\hline $\mathrm{d}_{2} / \mathrm{j}_{1}$ & 900 & 620 & 820 & 2,340 & 780 \\
\hline $\mathrm{d}_{3} / \mathrm{j}_{1}$ & 900 & 720 & 600 & 2,220 & 740 \\
\hline $\mathrm{d}_{1} / \mathrm{j}_{2}$ & 800 & 520 & 740 & 2,060 & 687 \\
\hline $\mathrm{d}_{2} / \mathrm{j}_{2}$ & 700 & 1,600 & 1,400 & 3,700 & 1,233 \\
\hline $\mathrm{d}_{3} / \mathrm{j}_{2}$ & 1,500 & 1,200 & 1,000 & 3,700 & 1,233 \\
\hline Total & 5,140 & 5,060 & 4,990 & 15,190 & 5,063 \\
\hline
\end{tabular}

\begin{tabular}{|l|r|r|r|r|r|}
\hline \multicolumn{1}{|c|}{ Source of Variation } & \multicolumn{1}{c|}{ df } & \multicolumn{1}{c|}{ Sum of Square } & \multicolumn{1}{c|}{ Mean Square } & \multicolumn{1}{c|}{ F-test } & \multicolumn{1}{c|}{ F-Table (0,05) } \\
\hline Type of Nypa Palm & 1 & $772,938.889$ & $772,938.89$ & 3.54 & 4.76 \\
\hline Dose/J & 4 & $873,888.889$ & $218,472.22$ & $3.70^{*}$ & 3.28 \\
\hline Error & 12 & 708,200 & $59,016.67$ & & \\
\hline Total & 17 & $2,355,027.78$ & & & \\
\hline
\end{tabular}

$*=$ Significantly

Appendix 2. Data of produced sap amount ( $\mathrm{ml}$ ) of various treatments obtained in the third week andAnalysis of Variance

\begin{tabular}{|c|c|c|c|c|c|}
\hline \multirow{2}{*}{ Treatments } & \multicolumn{3}{|c|}{ Block } & \multirow{2}{*}{ Total } & \multirow{2}{*}{ Mean } \\
\hline & 1 & 2 & 3 & & \\
\hline $\mathrm{d}_{1} / \mathrm{j}_{1}$ & 400 & 380 & 410 & 1,190 & 396 \\
\hline $\mathrm{d}_{2} / \mathrm{j}_{1}$ & 870 & 500 & 580 & 1,950 & 650 \\
\hline $\mathrm{d}_{3} / \mathrm{j}_{1}$ & 900 & 720 & 510 & 2,130 & 710 \\
\hline $\mathrm{d}_{1} / \mathrm{j}_{2}$ & 700 & 560 & 600 & 1,860 & 620 \\
\hline $\mathrm{d}_{2} / \mathrm{j}_{2}$ & 660 & 1,500 & 1,300 & 3,460 & 1,153 \\
\hline $\mathrm{d}_{3} / \mathrm{j}_{2}$ & 1,400 & 900 & 1,300 & 3,600 & 1,200 \\
\hline Total & 4,930 & 4,560 & 4,700 & 14,190 & 4,730 \\
\hline
\end{tabular}

\begin{tabular}{|l|r|r|r|r|r|}
\hline \multicolumn{1}{|c|}{ Source of Variation } & \multicolumn{1}{c|}{ df } & \multicolumn{1}{c|}{ Sum of Square } & Mean Square & \multicolumn{1}{c|}{ F-test } & F-Table (0,05) \\
\hline Kind & 1 & $740,138.889$ & $740,138.89$ & 3.75 & 4.76 \\
\hline Dosage/J & 4 & $788,977.778$ & $197,244.44$ & $3.44^{*}$ & 3.28 \\
\hline Galat & 12 & $687,933.333$ & $57,327.78$ & & \\
\hline Total & 17 & $2,217,050.000$ & & & \\
\hline
\end{tabular}

$*$ = significantly

Appendix 3. Data of produced sap amount (ml) of various treatments obtained in the fourth week andAnalysis of Variance

\begin{tabular}{|c|r|r|r|r|r|}
\hline \multirow{2}{*}{ Treatments } & \multicolumn{3}{|c|}{ Block } & \multirow{2}{*}{ Total } & \multirow{2}{*}{ Mean } \\
\cline { 2 - 5 } & \multicolumn{1}{|c|}{$\mathbf{2}$} & \multicolumn{2}{|c|}{$\mathbf{3}$} & & 467 \\
\hline $\mathrm{d}_{1} / \mathrm{j}_{1}$ & 370 & 580 & 450 & 1,400 & 767 \\
\hline $\mathrm{d}_{2} / \mathrm{j}_{1}$ & 900 & 600 & 800 & 2,300 & 710 \\
\hline $\mathrm{d}_{3} / \mathrm{j}_{1}$ & 900 & 720 & 510 & 2,130 & 740 \\
\hline $\mathrm{d}_{1} / \mathrm{j}_{2}$ & 1,000 & 700 & 520 & 2,220 & 1,213 \\
\hline $\mathrm{d}_{2} / \mathrm{j}_{2}$ & 1,500 & 1,460 & 680 & 3,640 & 1,167 \\
\hline $\mathrm{d}_{3} / \mathrm{j}_{2}$ & 1,400 & 800 & 1,300 & 3,500 & 5,063 \\
\hline Total & 6,070 & 4,860 & 4,260 & 15,190 & \\
\hline
\end{tabular}

\begin{tabular}{|l|r|r|r|r|r|}
\hline \multicolumn{1}{|c|}{ Source of Variation } & \multicolumn{1}{c|}{ Df } & \multicolumn{1}{c|}{ Sum of Square } & Mean Square & F-test & \multicolumn{1}{c|}{ F-Tabel (0,05) } \\
\hline Kind & 1 & $692,272.222$ & $692,272.22$ & $4.94 *$ & 4.76 \\
\hline Dosage/J & 4 & $560,688.889$ & $140,172.22$ & 1.88 & 3.28 \\
\hline Galat & 12 & $897,066.667$ & $74,755.56$ & & \\
\hline Total & 17 & $2,150,027.708$ & & & \\
\hline
\end{tabular}

$*$ = Significantly 
Effect of Lime and TanninDosage Against Productivity of Sap of Natural and Planted Nypa Palm...

Appendix 4. Data of produced sap amount $(\mathrm{ml})$ of various treatments obtained in the fifth week and Analysis of Variance

\begin{tabular}{|c|c|c|c|c|c|}
\hline \multirow{2}{*}{ Treatments } & \multicolumn{3}{|c|}{ Block } & \multirow{2}{*}{ Total } & \multirow{2}{*}{ Mean } \\
\hline & 1 & 2 & 3 & & \\
\hline $\mathrm{d}_{1} / \mathrm{j}_{1}$ & 350 & 330 & 400 & 1,080 & 360 \\
\hline $\mathrm{d}_{2} / \mathrm{j}_{1}$ & 530 & 800 & 570 & 1,900 & 633 \\
\hline $\mathrm{d}_{3} / \mathrm{j}_{1}$ & 550 & 800 & 850 & 2,200 & 733 \\
\hline $\mathrm{d}_{1} / \mathrm{j}_{2}$ & 720 & 560 & 620 & 1,900 & 633 \\
\hline $\mathrm{d}_{2} / \mathrm{j}_{2}$ & 1,000 & 1,500 & 600 & 3,100 & 1,033 \\
\hline $\mathrm{d}_{3} / \mathrm{j}_{2}$ & 1,300 & 620 & 1,320 & 3,240 & 1,080 \\
\hline Total & 4,450 & 4,610 & 4,360 & 13,420 & 4,473 \\
\hline
\end{tabular}

\begin{tabular}{|l|r|r|r|r|r|}
\hline \multicolumn{1}{|c|}{ Source of Variation } & \multicolumn{1}{c|}{ df } & Sum of Square & Mean Square & \multicolumn{1}{c|}{ F-test } & F-Table (0,05) \\
\hline Kind & 1 & $520,200.000$ & $520,200.00$ & 3.55 & 4.76 \\
\hline Dosage/J & 4 & $585,777.778$ & $146,444.44$ & 2.11 & 3.28 \\
\hline Galat & 12 & $834,066.667$ & $69,505.56$ & & \\
\hline Total & 17 & $1.940,044.440$ & & & \\
\hline
\end{tabular}

* = Significantly

Appendix 5. Data of produced sap amount $(\mathrm{ml})$ of various treatments obtained in the sixth week andAnalysis of Variance

\begin{tabular}{|c|c|c|c|c|c|}
\hline \multirow{2}{*}{ Treatments } & \multicolumn{3}{|c|}{ Block } & \multirow{2}{*}{ Total } & \multirow{2}{*}{ Mean } \\
\hline & 1 & 2 & 3 & & \\
\hline $\mathrm{d}_{1} / \mathrm{j}_{1}$ & 450 & 500 & 550 & 1,500 & 500 \\
\hline$\frac{d_{2} / 1}{d_{2} / j_{1}}$ & 600 & 700 & 580 & 1,880 & 627 \\
\hline $\mathrm{d}_{3} / \mathrm{j}_{1}$ & 650 & 800 & 900 & 2,350 & 783 \\
\hline $\mathrm{d}_{1} / \mathrm{j}_{2}$ & 900 & 660 & 720 & 2,280 & 760 \\
\hline $\mathrm{d}_{2} / \mathrm{j}_{2}$ & 1,100 & 1,300 & 800 & 3,200 & 1,067 \\
\hline $\mathrm{d}_{3} / \mathrm{j}_{2}$ & 1,400 & 800 & 1,400 & 3,600 & 1,200 \\
\hline Total & 5,100 & 4,760 & 4,950 & 14,810 & 4,937 \\
\hline
\end{tabular}

\begin{tabular}{|l|r|r|r|r|r|}
\hline \multicolumn{1}{|c|}{ Source of Variation } & \multicolumn{1}{c|}{ df } & Sum of Square & \multicolumn{1}{c|}{ Mean Square } & \multicolumn{1}{c|}{ F-test } & \multicolumn{1}{c|}{ F-Table (0,05) } \\
\hline Kind & 1 & $623,472.222$ & $623,472.22$ & $5.85^{*}$ & 4.76 \\
\hline Dosage/J & 4 & $426,288.889$ & $106,572.22$ & 2.89 & 3.28 \\
\hline Galat & 12 & 442.800 & $36,900.00$ & & \\
\hline Total & 17 & $1,492,561.110$ & & & \\
\hline
\end{tabular}

* = Significantly

Appendix 6. Data of produced sap amount (ml) of various treatments obtained in the seventh week and Analysis of Variance

\begin{tabular}{|c|r|r|r|r|r|}
\hline \multirow{2}{*}{ Treatments } & \multicolumn{3}{|c|}{ Block } & \multirow{2}{*}{ Total } & \multicolumn{2}{c|}{ Mean } \\
\cline { 2 - 3 } & $\mathbf{1}$ & $\mathbf{2}$ & \multicolumn{1}{|c|}{$\mathbf{3}$} & & 533 \\
\hline $\mathrm{d}_{1} / \mathrm{j}_{1}$ & 550 & 500 & 550 & 1,600 & 650 \\
\hline $\mathrm{d}_{2} / \mathrm{j}_{1}$ & 650 & 700 & 600 & 1,950 & 750 \\
\hline $\mathrm{d}_{3} / \mathrm{j}_{1}$ & 700 & 850 & 700 & 2,250 & 760 \\
\hline $\mathrm{d}_{1} / \mathrm{j}_{2}$ & 900 & 660 & 720 & 2,280 & 1,067 \\
\hline $\mathrm{d}_{2} / \mathrm{j}_{2}$ & 1,100 & 1,300 & 800 & 3,200 & 1,200 \\
\hline $\mathrm{d}_{3} / \mathrm{j}_{2}$ & 1,400 & 800 & 1,400 & 3,600 & 4,960 \\
\hline Total & 5,300 & 4,810 & 4,770 & 14,880 & \\
\hline
\end{tabular}

\begin{tabular}{|l|r|r|r|r|r|}
\hline \multicolumn{1}{|c|}{ Source of Variation } & \multicolumn{1}{c|}{ db } & \multicolumn{1}{c|}{ Sum of Square } & \multicolumn{1}{c|}{ Mean Square } & \multicolumn{1}{c|}{ F-test } & \multicolumn{1}{c|}{ F-Table (0,05) } \\
\hline Kind & 1 & $597,688.889$ & $597,688.89$ & $6.36^{*}$ & 4.76 \\
\hline Dosage/J & 4 & $375,977.778$ & $93,994.44$ & 2.69 & 3.28 \\
\hline Galat & 12 & $419,533.333$ & $34,961.11$ & & \\
\hline Total & 17 & $1,393,200.000$ & & & \\
\hline
\end{tabular}

* = Significantly

Appendix 7. Data of produced sap amount (ml) of various treatments obtained in the eight week and Analysis of Variance

\begin{tabular}{|c|r|r|r|r|r|}
\hline \multirow{2}{*}{ Treatments } & \multicolumn{3}{|c|}{ Block } & \multirow{2}{*}{ Total } & \multicolumn{2}{c|}{ Mean } \\
\cline { 2 - 4 } & $\mathbf{1}$ & \multicolumn{2}{|c|}{$\mathbf{2}$} & $\mathbf{3}$ & 543 \\
\hline $\mathrm{d}_{1} / \mathrm{j}_{1}$ & 400 & 480 & 750 & 1,630 & 600 \\
\hline $\mathrm{d}_{2} / \mathrm{j}_{1}$ & 600 & 630 & 570 & 1,800 & 680 \\
\hline $\mathrm{d}_{3} / \mathrm{j}_{1}$ & 630 & 830 & 580 & 2,040 & 793 \\
\hline $\mathrm{d}_{1} / \mathrm{j}_{2}$ & 1,000 & 660 & 720 & 2,380 & 967 \\
\hline $\mathrm{d}_{2} / \mathrm{j}_{2}$ & 800 & 1,300 & 800 & 2,900 & 1,133 \\
\hline $\mathrm{d}_{3} / \mathrm{j}_{2}$ & 1,200 & 800 & 1,400 & 3,400 & 4,717 \\
\hline Total & 4,630 & 4,700 & 4,820 & 14,150 & \\
\hline
\end{tabular}

\begin{tabular}{|l|r|r|r|r|r|}
\hline Source of Variation & \multicolumn{1}{|c|}{ Df } & Sum of Square & Mean Square & \multicolumn{1}{c|}{ F-test } & \multicolumn{1}{c|}{ F-Table (0,05) } \\
\hline Kind & 1 & $572,450.000$ & $572,450.00$ & $11.35^{*}$ & 4.76 \\
\hline Dosage/J & 4 & $201,711.111$ & $50,427.78$ & 1.16 & 3.28 \\
\hline Galat & 12 & $523,266.667$ & $43,605.56$ & & \\
\hline Total & 17 & $1,297,427.780$ & & & \\
\hline
\end{tabular}

* = Significantly 